\title{
Comparison of the muscle activity in the normal and forward head postures based on the pressure level during cranio-cervical flexion exercises
}

\author{
Donghoon Kang, Taeyoung Oh \\ Department of Physical Therapy, Silla University, Busan, Korea
}

\begin{abstract}
Purpose: This paper proposes proper and effective neck exercises by comparing the deep and superficial cervical flexor muscle activities and thickness according to the pressure level during cranio-cervical flexion exercises between a normal posture group and forward head posture group.

Methods: A total of 20 subjects (8 males and 12 females) without neck pain and disabilities were selected. The subjects' craniovertebral angles were measured; they were divided into a normal posture and a forward head posture group. During cranio-cervical flexion exercises, the thickness of the deep cervical flexor neck muscle and the activity of the surface neck muscles were measured using ultrasound and EMG.

Results: The results showed that the thickening of the deep cervical flexor was increased significantly to 28 and $30 \mathrm{mmHg}$ in the forward head posture group. The sternocleidomastoid muscle activity increased significantly to $24,26,28$, and $30 \mathrm{mmHg}$ in the forward head posture group. The anterior scalene muscle activity increased significantly to 26,28 , and $30 \mathrm{mmHg}$ in the forward head posture group. A significant difference of 26,28 , and $30 \mathrm{mmHg}$ in the sternocleidomastoid and anterior scalene muscles was observed between two groups.

Conclusion: To prevent a forward head posture and maintain proper cervical curve alignment, the use of the superficial cervical flexor muscles must be minimized. In addition, to perform a cranio-cervical flexion exercises to effectively activate the deep cervical flexor muscles, 28 and $30 \mathrm{mmHg}$ for normal posture adults and $28 \mathrm{mmHg}$ for adults with forward head postures are recommended.
\end{abstract}

Keywords: Posture, Neck muscles, Craniocervical, Exercises

\section{서 론}

근골격계 질환에서 목 통증은 현대인들에게 가장 흔하게 발생하는 질환으로 알려져 있다. 인구의 $67 \%$ 가 일생에 한 번 이상 경험하게 되 고, 유병률은 연구마다 29-76\%까지 다양하게 보고된다. 목 통증의 원 인으로는 머리를 고정하기 위해 오랜 시간 목 근육의 수축이 지속되 어야 하므로 목 근육의 약화로 인한 피로의 누적, 잘못된 자세나 습 관으로 인하여 역학적인 통증(mechanical pain)으로 발생한다.3-6

정상적인 머리 자세는 귀구슬(tragus)과 봉우리 각(acromial angle) 이 수직 선상에 놓여 있는 반면, 앞쪽 머리 자세(forward head posture) 는 바로 선 자세에서 귀 구슬과 봉우리 각 사이의 수평거리가 $5 \mathrm{~cm}$ 이 상이고, 아래쪽 목뼈의 굽힘과 위쪽 목뼈의 과도한 폄을 동반하는 자
세이다. ${ }^{7}$

여러 선행연구에서 앞쪽 머리 자세에 따른 다양한 변화들을 다루 었는데, Yip 등은, 앞쪽 머리 자세를 가지고 있는 대상자들은 정상적 인 자세를 가지고 있는 대상자들보다 목 통증이 증가하였음을 보고 하였고, 목의 얕은목굽힘근인 목빗근(sternocleidomastoid muscle)과 앞목갈비근(anterior scalene muscle) 등의 과도한 활성화로 인해 깊은 목굽힘근(deep cervical flexor)의 활동이 억제되어, ${ }^{,}$목뼈 관절의 안정 성이 결여되는 결과를 유발한다.10

최근 올바른 목뼈의 자세조절을 위하여 깊은목굽힘근의 역할의 중 요성과 활성도를 증가하는 방법에 관한 연구들이 많이 보고되고 있 다. 그중, 머리-목 굽힘운동(cranio-cervical flexion exercise)은 목빗근, 앞 목갈비근과 같은 얕은목굽힘근들의 사용을 최소화하고, 깊은목굽힘 
근인 목긴근, 머리긴근의 활성도를 증가시키는 운동으로써 환자 또는 건강한 사람을 대상으로 임상에서 주로 사용되고 있다."1

하지만 여전히 머리-목 굽힘 운동에 관한 연구는 부족한 실정이다. 앞선 연구들에서는 목의 자세에 따른 머리-목 굽힘 운동 시 깊은목 굽힘근과 얕은목굽힘근들의 활성도에 대한 비교와 깊은목굽힘근을 활성화하고 얕은목굽힘근을 최소한으로 사용되는 적절한 압력 정 도를 제시하기에는 부족하였다.

따라서 본 연구의 목적은 선행 연구의 부족한 실정을 보완하여 통 증에 따른 머리-목 굽힘 운동 시 근 활성도 정도 차이가 아닌 자세에 따른 깊은목굽힘근과 얕은목굽힘근들의 활성화 정도를 살펴보기 위해 머리-목 굽힘 운동 시 압력에 따라 정상 자세와 앞쪽 머리 자세 를 가진 성인의 깊은목굽힘근과 얕은목굽힘근의 활성도를 비교 분 석하여 머리-목 굽힘 운동 시 올바르고 효과적인 압력의 정도를 제시 하고자 한다.

\section{연구 방법}

\section{1. 연구대상}

본 연구의 대상자는 부산 소재의 20-30대 남녀 성인을 대상으로 하여 목과 관련하여 시각 통증 등급 0 점, 목 장애지수 0 에서 4 점 사이인 건 강한 성인 20 명(남자 8 명, 여자 12 명)을 선정하였다. 다른 질환에 의한 심각한 손상이나 신경학적 질환이 있는 자, 수술을 받은 경험이 있는 자, 최근 3 개월 이내 목뼈 관절의 치료 이력이 있는 대상자는 연구에 서 제외하였다. 대상자는 실험에 앞서 실험에 관한 절차와 방법에 대 한 설명을 충분히 한 후 자발적으로 실험 동의서를 작성한 후, 본 연 구에 참여하였다(Table 1).

\section{2. 측정도구}

1) 압력 바이오 피드백(Pressure biofeedback unit) 대상자들의 머리-목 굽힘 운동 시 수축을 일정하게 측정하기 위해압

Table 1. Demographic characteristics of subjects in each group

\begin{tabular}{lcccc}
\hline & FHP $(n=10)$ & $\operatorname{NHP}(n=10)$ & $t$ & $p$ \\
\hline Gender & 4 & 4 & & \\
Male & 6 & 6 & & \\
Female & $32.4 \pm 4.42^{+}$ & $29.7 \pm 3.56$ & 0.347 & 0.150 \\
Age (yr) & $166.7 \pm 7.55$ & $166.9 \pm 6.57$ & 0.441 & 0.950 \\
Height (cm) & $59.2 \pm 12.38$ & $60.5 \pm 11.60$ & 0.423 & 0.811 \\
Weight (kg) & $45.78 \pm 1.05$ & $54.09 \pm 1.05$ & 2.891 & $0.000^{*}$ \\
CVA &
\end{tabular}

FHP: forward head posture, NHP: normal head posture, CVA: craniovertebral angle.

${ }^{+}$Mean \pm SD; * $p<0.05$.
력 바이오피드백 기구를 사용하였다. 압력 바이오피드백 기구는 공 기주머니, 압력표시계, 공기펌프로 구성되어 있는데, 근육의 수축으 로 발생된 힘이 공기주머니에 압력을 가하여, 압력 정도가 압력표시 계에 수치로 나타내어 근육의 수축력 정도를 측정할 수 있다.12

\section{2) 표면근전도(Surface electromyograph)}

본 연구에서는 머리-목 굽힘 운동을 수행하는 동안 얕은목굽힘근들 의 근활성도를 측정하기 위해 표면근전도 측정 장비인 $2 \mathrm{EM}$ (4D-MT, Relive, Korea)을 사용하였다.

\section{3) 초음파 영상장치|(Ultra Sonic Imaging)}

본 연구에서는 머리-목 굽힘 운동을 수행하는 동안 깊은목굽힘근의 목긴근 두께 변화를 측정하기 위하여 초음파 영상장치(IE33, Philips medical systems, Germany)를 사용하였다. 초음파는 근골격계 검사에 서 근육의 활성 패턴을 측정하기 위하여 근육의 두께를 측정할 수 있 으며, 선택적으로 깊은근 수축 훈련과 근육의 위축 비대, 생체되먹임 을 통한 훈련방법의 교육 및 수정 등을 할 수 있는 장비이다. ${ }^{13}$

\section{3. 실험 절차}

\section{1) 머리-척추각(Cranio-vertebral angle) 측정}

머리-척추각은 앞쪽 머리 자세를 평가하기 위해 사용되는 검증된 방 법이다. ${ }^{14}$ 측정을 위해 대상자의 일곱 번째 목뼈 가시돌기 위에 표식

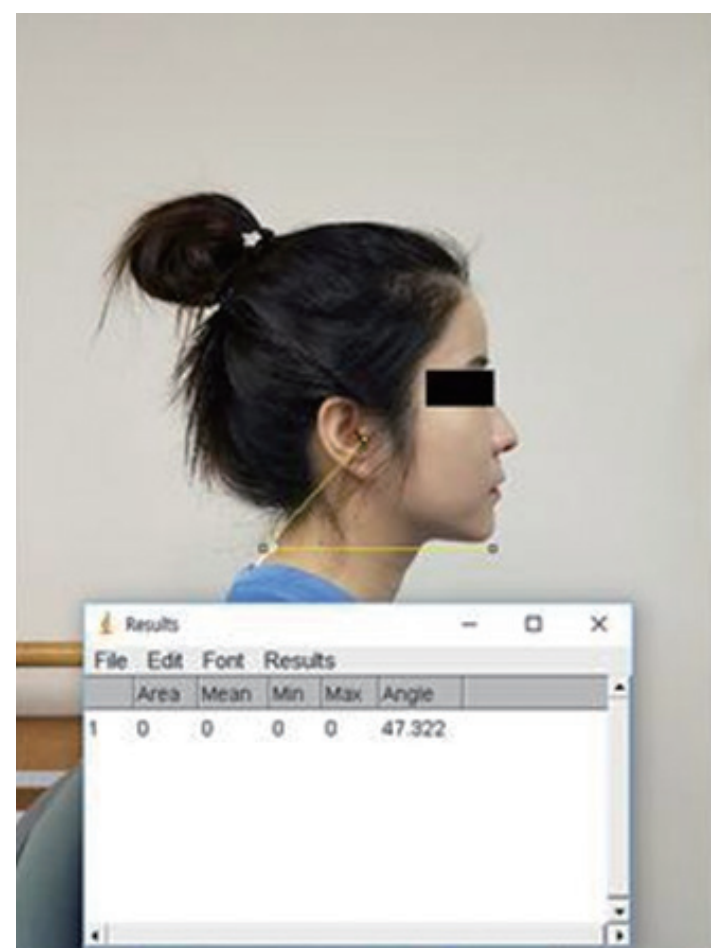

Figure 1. Craniovertebral angle. 
을 부착하여 촬영하였고, 촬영 후 이미지에서 대상자의 귀구슬과 일 곱 번째 목뼈의 가시돌기를 연결한 선과 수평선이 이루는 각도를 NIH image J ver 1.47 (Sun Microsystems Inc., USA)의 프로그램을 이용 하여 각도를 계산하였다(Figure 1). Nemmers 등 15 의 연구에 의하면 45 세 이하의 성인의 정상적인 머리-척추각은 $49^{\circ}$ 에서 $59^{\circ}$ 의 범위를 가진 다고 보고하였다. 이에 따라 본 연구는 머리-척추각에 따라 앞쪽 머 리 자세의 앞쪽 머리 자세군은 $49^{\circ}$ 미만, 정상 자세의 정상 자세군은 $49^{\circ}$ 에서 $59^{\circ}$ 사이의 범위로 나누어 각 군 당 10 명씩 배정하였다.

\section{2) 머리-목 굽힘 운동}

머리-목 굽힘 운동은 올바른 목뼈 정렬을 위한 목의 안정화 운동으 로 환자 또는 건강한 사람을 대상으로 임상에서 많이 사용되는 운동 방법이다." 또한, Hudswell 등 ${ }^{16}$ 은 머리-목 굽힘 운동은 깊은목굽힘근 의 활성 정도를 측정하는 데 높은 신뢰도를 나타낸다고 보고하였다. 대상자는 바르게 누워 엉덩관절 $60^{\circ}$ 굽힘과 무릎관절 $90^{\circ}$ 굽힘을 유 지한자세에서 압력 바이오피드백 기구를 뒤통수 뼈 아래, 위쪽 목뼈 부위에 위치하여 머리-목 굽힘 운동을 시행하였다. 머리-목 굽힘 운 동 시, 압력 바이오피드백 기구의 압력표시계는 대상자의 눈에서 정 면으로 위치하였고, 정확한 측정을 위하여 대상자 팔의 사용을 억제 하기 위해 고정하여 설치하였다. 휴지기인 $20 \mathrm{mmHg}$ 에서 22, 24, 26, $28,30 \mathrm{mmHg}$ 까지 $2 \mathrm{mmHg}$ 의 압력을 증가시켜 총 6단계의 압력에서 시행하였으며, ${ }^{17}$ 압력마다 10 초간 유지한 후 2 분간 휴식을 취하였다.

\section{3) 근전도 측정}

근전도 신호의 표본 추출률(sampling rate)은 $1,000 \mathrm{~Hz}$ 로 설정하고, 주 파수 대역폭(bandpass)은 $20-450 \mathrm{~Hz}$ 를 사용하였으며, 근전도 신호는 제곱평균제곱근법(root mean square, RMS)으로 처리하여 분석하였다.

전극은 전극 간의 거리를 $2 \mathrm{~cm}$ 로 유지하여 근섬유 방향에 평행하 게 부착하였으며, 부착 전 근전도 신호에 대한 피부 저항을 감소시키 기 위해 부착 부위를 가는 사포로 3-4회 문질러 피부 각질층을 제거 하고, 소독용 알코올로 닦아내었다. 전극은 우측 목빗근과 앞목갈비 근에 부착하였으며, 목빗근은 꼭지돌기와 빗장뼈의 중간 지점, 앞목 갈비근은 목빗근으로부터 가쪽으로 이동하여 빗장뼈와 위등세모근 윗부분이 이루는 삼각형 지점에 부착하였다. ${ }^{18}$

얕은목굽힘근의 활성도를 정규화(normalization)하기 위해, 최대 등척성 수의적 수축(maximal voluntary isometric contraction, MVIC) 시 근 활성도를 측정하여 제곱평균제곱근법으로 처리된 각 근육의 활성도를 백분율 $\% \mathrm{MVIC})$ 로 분석하였다. 최대 등척성 수의적 수축 정도의 측정을 위해 대상자는 머리-목 굽힘 운동 시행 자세를 취하고 목을 앞쪽 굽힘 시, 검사자는 대상자 이마에 저항을 제공한다. 최대 등척성 수의적 수축 정도의 측정은 7 초간 3 회 측정하는데, 처음과 마

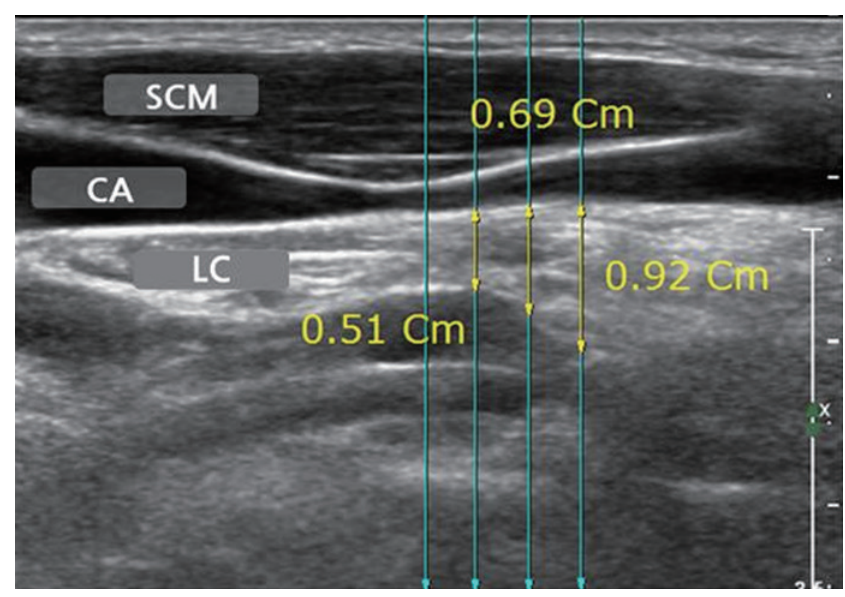

Figure 2. Ultrasonographic of SCM, CA, LC.

SCM: sternocleidomastoid muscle, CA: carotid artery, LC: Longus colli muscle.

지막 1 초를 제외한 값의 3 회 평균값을 사용하였다.

4) 초음파 촬영 및 측정

머리-목 굽힘 운동 시 초음파의 탐촉자(probe)를 대상자의 기관(trachea)에서 오른쪽으로 $5 \mathrm{~cm}$ 떨어진 부위에 세로 방향으로 평행하게 위치하였다. 초음파 장비의 화면을 통해 나오는 영상에서 목빗근, 목 동맥, 고리판(laminae)의 영상이 잘 보이도록 위치를 조절하였으며, ${ }^{19}$ 세 번 반복 측정하여 촬영 영상이 가장 깨끗한 이미지를 선택하여 의 료 영상 저장전송 시스템(picture archiving and communication system, PACS)을 이용하여 결과 값을 측정하였다.

측정방법은 이미지 중앙에 기준선을 그어 중앙선으로부터 각각 1 $\mathrm{cm}, 2 \mathrm{~cm}, 3 \mathrm{~cm}$ 간격으로 수직선을 그어 세 개의 수직선에 위치된 목 긴근의 두께를 측정하는데, 목동맥과 목긴근 위쪽 근막 경계부에서 부터, 아래쪽 고리판의 경계부 사이의 거리를 측정하였다. 세 개의 수 직선에 측정된 선의 길이를 평균값으로 산출하였다(Figure 2). ${ }^{19}$

\section{4. 분석 방법}

머리, 목 굽힘 운동 시 발생 된 압력에 따라 정상 자세군과 앞쪽 머리 자세군의 목긴근 두께 변화, 목빗근과 앞목갈비근 활성도를 비교하 기 위해 반복측정 분산분석(repeated measures ANOVA)을 실시하였 으며, 유의수준은 $\alpha=0.05$ 로 하였다. 사후검정은 본페로니 교정(Bonferroni correction)을 시행하였으며 유의수준 $\alpha=0.01$ 로 하였다.

앞쪽 머리 자세군과 정상 자세군 간의 차이를 알아보기 위하여 독 립표본 t-검정(independent t-test)을 실시하였다.

통계처리는 SPSS for Windows (Ver. 22.0)를 사용하였다. 
Table 2. Comparison of DCF thickness according pressure level between FHP group and NHP group

(unit: $\mathrm{cm}$ )

\begin{tabular}{lcccccccccc}
\hline & & $20 \mathrm{mmHg}$ & $22 \mathrm{mmHg}$ & $24 \mathrm{mmHg}$ & $26 \mathrm{mmHg}$ & $28 \mathrm{mmHg}$ & $30 \mathrm{mmHg}$ & $\mathrm{F}$ & $\mathrm{p}$ \\
\hline LC & FHP & $0.71 \pm 0.05^{+}$ & $0.72 \pm 0.05$ & $0.71 \pm 0.05$ & $0.72 \pm 0.06$ & $0.72 \pm 0.05$ & $0.72 \pm 0.06$ & 163.788 \\
& $\mathrm{NHP}$ & $0.69 \pm 0.03$ & $0.71 \pm 0.03$ & $0.73 \pm 0.03$ & $0.77 \pm 0.04$ & $0.80 \pm 0.04$ & $0.84 \pm 0.04$ & $.000^{*}$ \\
$\mathrm{t}$ & 5.435 & 2.550 & 3.372 & 2.198 & 1.110 & 2.469 & \\
$\mathrm{p}$ & 0.470 & 0.578 & 0.359 & $0.026 *$ & $0.003^{*}$ & $0.000^{*}$ & \\
\hline
\end{tabular}

LC: longus colli muscle, FHP: forward head posture, NHP: normal head posture. ${ }^{+}$Mean \pm SD; ${ }^{*} \mathrm{p}<0.05$

Table 3. Comparison of SCM and AS activity according pressure level between FHP group and NHP group

(unit: \%)

\begin{tabular}{lccccccccc}
\hline & & $20 \mathrm{mmHg}$ & $22 \mathrm{mmHg}$ & $24 \mathrm{mmHg}$ & $26 \mathrm{mmHg}$ & $28 \mathrm{mmHg}$ & $30 \mathrm{mmHg}$ & $\mathrm{F}$ & $\mathrm{p}$ \\
\hline $\mathrm{SCM}(\% \mathrm{MVIC})$ & $\mathrm{FHP}$ & $12.91 \pm 2.25^{+}$ & $13.19 \pm 2.43$ & $13.50 \pm 2.41$ & $14.08 \pm 2.79$ & $15.14 \pm 3.10$ & $16.64 \pm 3.10$ & 39.968 \\
& $\mathrm{NHP}$ & $12.98 \pm 1.50$ & $13.33 \pm 1.67$ & $13.53 \pm 1.57$ & $13.63 \pm 1.70$ & $13.84 \pm 1.76$ & $14.18 \pm 1.72$ & $.000^{*}$ \\
$\mathrm{t}$ & & 3.206 & 2.754 & 3.430 & 3.663 & 3.565 & 4.956 & \\
$\mathrm{p}$ & & 0.939 & 0.880 & 0.976 & 0.670 & 0.266 & $0.046^{*}$ & \\
$\mathrm{AS}(\% \mathrm{MVIC})$ & $\mathrm{FHP}$ & $13.74 \pm 2.40$ & $14.04 \pm 2.20$ & $14.09 \pm 2.51$ & $14.96 \pm 2.67$ & $15.51 \pm 2.95$ & $17.11 \pm 2.93$ & 4.283 \\
& $\mathrm{NHP}$ & $13.38 \pm 1.28$ & $13.58 \pm 1.38$ & $13.53 \pm 1.45$ & $13.71 \pm 1.52$ & $13.97 \pm 1.67$ & $14.09 \pm 1.79$ & $.000^{*}$ \\
$\mathrm{t}$ & & 7.482 & 4.536 & 6.680 & 3.245 & 4.295 & 4.816 & \\
$\mathrm{p}$ & & 0.681 & 0.584 & 0.549 & 0.215 & 0.170 & $0.014^{*}$ & \\
\hline
\end{tabular}

SCM: sternocleidomastoid, AS: anterior scalene, FHP: forward head posture, NHP: normal head posture. ${ }^{+}$Mean \pm SD; ${ }^{*} p<0.05$.

\section{결 과}

\section{1. 연구 대상자의 특성}

본 연구 대상자의 특성은 Table 1과 같으며, 앞쪽 머리 자세군과 정상 자세군의 사전 동질성을 분석한 결과 군 간 유의한 차이는 없는 것으 로 나타났다. 앞쪽 머리 자세군과 정상 자세군 간의 머리-척추각의차 이를 비교 분석한 결과 군 간 유의한차이를 보였다.

\section{2. 압력에 따른 깊은목굽힘근 두께 분석}

앞쪽 머리 자세군 내 압력별 근 두께 차이는 휴지기 $20 \mathrm{mmHg}$ 와 비교했 을 때, $28,30 \mathrm{mmHg}$ 에서 통계학적인 유의한 증가를 나타냈다 $(\mathrm{p}<0.05)$. 정상 자세군은 모든 압력에 따라 통계학적으로 유의한 증가를 나타냈 다 $(\mathrm{p}<0.05)$ (Table 2).

압력별로 앞쪽 머리 자세군과 정상 자세군 간의 비교에서 $26 \mathrm{mmHg}$ 부터 $30 \mathrm{mmHg}$ 에서는 통계학적으로 유의한 차이가 있었다 $(\mathrm{p}<0.05)$.

\section{3. 압력에 따른 목빗근 활성도 분석}

앞쪽 머리 자세군은 $24 \mathrm{mmHg}$ 에서 $30 \mathrm{mmHg}$ 까지 압력에서 유의한 증가를 나타냈고, 정상 자세군은 $26 \mathrm{mmHg}$ 에서 $30 \mathrm{mmHg}$ 까지 압력 에서 유의한 증가를 나타냈다 $(\mathrm{p}<0.05)$ (Table 3).

압력별로 앞쪽 머리 자세군과 정상 자세군 간 비교분석 결과 30 $\mathrm{mmHg}$ 에서는 통계학적으로 유의한 차이가 있었다 $(\mathrm{p}<0.05)$.

\section{4. 압력에 따른 앞목갈비근 활성도 분석}

앞쪽 머리 자세군은 $26 \mathrm{mmHg}$ 에서 $30 \mathrm{mmHg}$ 까지의 압력에서 유의 한 증가를 나타냈지만 $(\mathrm{p}<0.05)$, 정상 자세군은 모든 압력에서 유의한 차이가 없었다 $(\mathrm{p}<0.05)($ Table 3$)$.

압력별로 앞쪽 머리 자세군과 정상 자세군 간 비교분석 결과 $30 \mathrm{mmHg}$ 의 압력에서는 통계학적으로 유의한차이가 있었다 $(\mathrm{p}<0.05)$.

\section{고 찰}

본 연구는 머리-목 굽힘 운동 시 발생 된 압력에 따라 정상 자세를 가 진 성인과 앞쪽 머리 자세를 지닌 성인의 근 활성도 차이를 비교하여 머리-목 굽힘 운동방법의 올바르고 효과적인 방법을 제시하기 위하 여 실시하였다. 앞쪽 머리 자세의 정도를 측정하는 다양한 방법이 있 는데 본 연구에서는 높은 신뢰도와 타당도를 보고한 머리-척추각을 측정하여 앞쪽 머리 자세군과 정상 자세군으로 나누어 연구를 진행 하였다. 머리-목 굽힘 운동 시 압력에 따른 깊은목굽힘근인 목긴근의 두께 변화와 얕은목근육인 목빗근과 앞목갈비근의 활성도를 군에 따라 비교하였다.

본 연구의 결과 깊은목굽힘근 두께 변화는 앞쪽 머리 자세군과 정 상자세군 모두 압력 증가에 따라 유의한 증가를 나타냈다. 정상 자세 군은 모든 압력에서 유의한 증가를 나타냈고, 앞쪽 머리 자세군에서는 휴지기 $20 \mathrm{mmHg}$ 와 비교했을 때, $28,30 \mathrm{mmHg}$ 에서 유의한 증가를 나 타냈다. 앞쪽 머리 자세군과 정상 자세군 간 비교에서는 $26,28,30$ 
$\mathrm{mmHg}$ 에서 유의한 차이를 나타냈다. Falla 등 ${ }^{9}$ 의 연구에서 머리, 목 굽 힘 운동 시 압력 증가에 따라 깊은목굽힘근의 활성도 증가량은 양의 상관관계가 있다는 연구 결과와 일치하며, Jesus 등 ${ }^{19}$ 의 목 통증이 없 는 정상 성인 10 명을 대상으로 한 연구에서 머리, 목 굽힘 운동 시 압 력이 증가함에 따라 깊은목굽힘근의 두께가 증가한 결과와도 일치하 였다. 이러한 결과는 깊은목굽힘근인 목긴근은 척추 중심축 앞쪽에 서 주행하여 근 활동이 이루어지고, 목뼈의 굽힘근으로 작용하여 머 리-목굽힘 운동 시 압력이 증가할수록 굽힘의 범위가 증가되므로 더 큰 근 활성을 필요로 인해 나타난 결과로 사료된다. 앞쪽 머리 자세군 에 대해 정상 자세군이 압력에 따라 활발한 근 활성도를 나타내었는 데, Ishida 등 20 의 연구에서 앞쪽 머리 자세를 가진 사람의 목긴근의 근 두께가 정상 자세를 가진 사람에 비해 감소하여 근 활성도가 낮아 진다는 결과와 일치하였다.

머리-목 굽힘 운동 시 압력에 따라 목빗근의 활성도를 살펴보면, 앞쪽 머리 자세군과 정상 자세군 모두 압력 증가에 따라 유의한 증가 를 나타냈다. 앞쪽 머리 자세군은 $26,28,30 \mathrm{mmHg}$ 에서 유의한 증가 를 나타냈고, 앞쪽 머리 자세군에서는 $24,26,28,30 \mathrm{mmHg}$ 에서 유의 한 증가를 나타냈다. 앞쪽 머리 자세군과 정상 자세군 간 차이에서는 $30 \mathrm{mmHg}$ 에서 유의한 차이를 보였다. 이는 목 통증이 없는 21 세에서 부터 53 세까지의 정상 성인 10 명을 대상으로 한 Falla 등 ${ }^{21}$ 의 연구와 목 통증이 없는 정상 성인 10 명을 대상으로 한 Jesus 등 ${ }^{19}$ 의 연구에서 머리-목 굽힘 운동 시 압력 증가에 따라 목빗근 활성의 증가를 나타 난 결과와 일치하였다. 이는 목의 굽힘을 담당하는 목빗근은 얕은 층 에서 목 뒤쪽의 유돌기에 정지하는 근육으로 머리, 목 굽힘 운동 시 위쪽 목빼에서 굽힘이 발생되어 목빗근의 활성도가 증가한 것으로 사료된다. 압력에 따른 근 활성도를 살펴보게 되면, Jesus 등 ${ }^{19}$ 의 목 통 증이 없는 정상 성인 10 명을 대상으로 한 연구에서 $26,28,30 \mathrm{mmHg}$ 의 단계에서 유의한 증가를 나타낸 결과와 본 연구의 정상 자세군에 서의 결과와 일치함을 확인할 수 있었다. 앞선 연구들과 유사하고 일 치된 결과를 보이는 것은 머리, 목 굽힘 압력이 증가함에 따라 위쪽 목뼈의 굽힘 증가로 목빗근의 활성이 더욱 요구되어 근 활성 증가가 나타난 것으로 사료된다. 머리, 목 굽힘 운동 시 $30 \mathrm{mmHg}$ 의 압력에서 앞쪽머리자세과 정상 자세군 간 유의한 차이를 보였는데, 이는 머리, 목 굽힘 운동 시 앞쪽 머리 자세를 지닌 대상자가 목빗근의 과도한 긴 장으로 목 앞쪽에 압박감을 주어 관절가동범위 제한을 유발하여 머 리-목 굽힘 검사의 수행을 어렵게 하므로 $922,30 \mathrm{mmHg}$ 의 높은 압력 에서는 다른 압력에 비해 높은 근 활성의 필요로 정상자세군에 비해 앞쪽 머리 자세군에서 근 활성도 증가가 나타난 것으로 사료된다.

머리-목 굽힘 운동 시 압력에 따라 앞목갈비근의 활성도를 살펴보 게 되면, 정상 자세군은 유의한 증가가 나타나지 않음과 달리, 앞쪽 머 리 자세군은 $26,28,30 \mathrm{mmHg}$ 에서 유의한 증가를 나타냈다. 앞쪽 머리
자세군과 정상 자세군 간 차이에서는 $30 \mathrm{mmHg}$ 에서 유의한 차이를 보였다. Johnston 등 23 의 통증이 없는 정상 군과 통증이 있는 근로자 군을 대상으로 머리, 목 굽힘 운동 시 근 활성도를 비교한 연구에서 근로자 군의 $22,24,26,28,30 \mathrm{mmHg}$ 의 압력에서 앞목갈비근 활성도 가 유의한 증가가 나타난 결과와 유사한 결과를 보였다. 비록 통증을 호소하는 근로자를 대상으로 한 선행연구와 달리, 본 연구에서는 앞 쪽 머리 자세를 지닌 대상자를 선정하여 조건은 일치하지 않으나, 오 랜 기간 컴퓨터를 사용함에 따라 앞쪽 머리 자세를 유발한다는 여러 선행 연구들의 결과에 따라 근로자의 앞쪽 머리 자세군 또한, 앞쪽 머 리 자세가 유발된 것으로 볼 수 있다. 따라서 선행연구의 근로자 군과 본 연구의 앞쪽 머리 자세군에서 압력이 증가함에 따라 앞목갈비근 활성도가 유사하게 증가 된 것으로 사료된다.

앞쪽 머리 자세군과 정상 자세군 간 차이에서 목빗근과 마찬가지 로 $30 \mathrm{mmHg}$ 의 압력에서 유의한차이를 보였다. Falla 등 9 의 연구에 따 르면, 앞쪽 머리 자세로 인하여 깊은목굽힘근의 활동이 감소하여 30 $\mathrm{mmHg}$ 의 높은 압력에서 앞목갈비근과 같은 얕은목굽힘근의 활성도 증가로 머리, 목 굽힘 운동을 수행하기 위한 목 근육들의 운동 전략 이 재구성되어 정상 자세군에 비해 앞쪽 머리 자세군의 앞목갈비근 의 활성도 증가가 크게 나타난 것으로 사료된다.

본 연구에서 머리, 목 굽힘 운동 시 압력에 따라 정상 자세군에서 앞 쪽 머리 자세군에 비해 깊은목굽힘근인 목긴근 두께의 증가를 보였고, 앞쪽 머리 자세군에서는 정상 자세군에 비해 얕은목굽힘근들의 활성 도 증가를 보였다. 이는 여러 선행연구들과 일치된 결과를 나타냈다.

머리, 목 굽힘 운동 시 본 연구의 정상 자세군에서 깊은목굽힘근은 모든 압력에서 유의한 증가를 나타냈고, 앞쪽 머리 자세군에서는 28 , $30 \mathrm{mmHg}$ 의 압력에서 유의한 증가를 나타냈다. 앞쪽 머리 자세군과 정상 자세군 간 비교에서는 $26,28,30 \mathrm{mmHg}$ 의 압력에서 유의한 차이 를 나타냈다. 얕은목굽힘근들인 목빗근과 앞목갈비근의 활성도에서 는 $30 \mathrm{mmHg}$ 의 압력에서 정상 자세군과 앞쪽 머리 자세군 간 유의한 차이가나타났다.

이러한 결과를 종합했을 때, 깊은목굽힘근의 높은 활성과 얕은목 굽힘근 낮은 활성을 위해서는 정상 자세를 지닌 성인을 대상으로는 $26,28,30 \mathrm{mmHg}$ 의 압력이, 앞쪽 머리 자세를 지닌 성인은 $28 \mathrm{mmHg}$ 의 압력이 적절하다고 사료된다.

본 연구의 제한점으로 첫째, 연구 대상자가 충분한 숫자에 미치지 못하며 둘째, 깊은목근육과 얕은목근육의 활성도를 측정하기에 동 시적인 검사가 이루어지지 못했다는 점이다. 초음파 영상으로 깊은 목근육과 얕은목근육 중 목빗근의 활성도 측정은 동시에 가능하지 만, 앞목갈비근 활성도를 측정하는 데에는 제한이 있어, 앞목갈비근 의 활성도를 확인하기 위해 초음파와 근전도, 두 차례의 실험을 각각 진행하였다는 점이다. 향후 본 연구에서 나타난 제한점을 보완할 수 
있도록 지속적인 연구가 필요할 것이다.

\section{REFERENCES}

1. Vernon H. The Neck Disability Index: state-of-the-art, 1991-2008. Journal of Manipulative \& Physiological Therapeutics. 2008;31(7):491-502.

2. Kim SH, Kang KW, Lee KW. A correlation study on pain, range of motion of neck, neck disability index and grip strength after thoracic manipulation and cervical stabilization training in chronic neck pain. J Kor Phys Ther. 2017;29(4):158-63

3. Cailliet R, Eccles A. Soft tissue pain and disability. Philidelphia, FA Davis. 1996:101-70.

4. Janda V. Muscles and motor control in cervicogenic disorders. Assessment and management. Physical therapy of the cervical and thoracic spine. 1994

5. Viljanen M. Malmivaara A. Uitti J et al. Effectiveness of dynamic muscle training, relaxation training, or ordinary activity for chronic neck pain: randomised controlled trial. BMJ. 2003;327(7413):475.

6. Cagnie B, Cools A, Deloose V et al. Differences in isometric neck muscle strength between healthy controls and women with chronic neck pain: the use of a reliable measurement. Arch Phys Med Rebabil. 2007;88(11): 1441-45.

7. Hanten WP, Lucio RM, Russell JL et al. Assessment of total head excursion and resting head posture. Arch Phys Med Rehabil. 1991;72(11): $877-80$.

8. Yip CHT, Chiu TTW, Poon ATK. The relationship between head posture and severity and disability of patients with neck pain. Man Ther. 2008;13(2):148-54.

9. Falla DL, Jull GA, Hodges PW. Patients with neck pain demonstrate reduced electromyographic activity of the deep cervical flexor muscles during performance of the craniocervical flexion test. Spine. 2004; 29(19):2108-14.

10. Winters JM, Peles JD. Neck muscle activity and 3-D head kinematics during quasi-static and dynamic tracking movements. Multiple Muscle Systems. 1990:461-80.

11. Cagnie B, Dirks R, Schouten M et al. Functional reorganization of cervical flexor activity because of induced muscle pain evaluated by muscle functional magnetic resonance imaging. Manual Therapy. 2011;16(5): 470-5.

12. Chang JS, Lee JH. Comparison of cervical flexor muscles thickness during cranial-cervical flexor exercise according to pressure levels and eye directions in healthy subjects. J Kor Phys Ther. 2015:27(1):50-4.

13. Jun DH. Effect of arm movement with cranio-cervical flexion test on muscle activity. Daegu University. Dissertation of Masters's Degree. 2012.

14. Watson DH, Trott PH. Cervical headache: an investigation of natural head posture and upper cervical flexor muscle performance. Cephalalgia. 1993;13(4):272-84.

15. Nemmers TM, Miller J W, Hartman MD. Variability of the forward head posture in healthy community-dwelling older women. J Geroatr Phys Ther. 2009;32(1):10-4.

16. Hudswell S, Von Mengersen M, Lucas N. The cranio-cervical flexion test using pressure biofeedback: a useful measure of cervical dysfunction in the clinical setting?. Int J Osteopath Med. 2005;8(3):98-105.

17. Kim SH, Park JS. Effects of the neck stabilization exercises with vibratory stimulation on the neck disability index and thickness of deep neck flexor in neck pain patient. J Kor Phys Ther. 2017;29(5):265-70.

18. Cram JR. Cram's introduction to surface electromyography. Gaithersburg, Aspen publishers, 2011.

19. Jesus FM, Ferreira PH, Ferreira ML. Ultrasonographic measurement of neck muscle recruitment: a preliminary investigation. J Man Manip Ther. 2008;16(2):89-92.

20. Ishida H, Suehiro T, Kurozumi C et al. Correlation between neck slope angle and deep cervical flexor muscle thickness in healthy participants. J Bodyw Mov Ther. 2015;19(4):717-21.

21. Falla D, Jull G, Dall'Alba P et al. An electromyographic analysis of the deep cervical flexor muscles in performance of craniocervical flexion. Physical Therapy. 2003;83(10):899-906.

22. Quek J, Pua YH, Clark RA et al. Effects of thoracic kyphosis and forward head posture on cervical range of motion in older adults. Manual Therapy. 2013;18(1):65-71.

23. Johnston V, Jull G, Souvlis T et al. Neck movement and muscle activity characteristics in female office workers with neck pain. Spine. 2008; 33(5):555-63. 